Journal of

Innate Immunity
Editorial

J Innate Immun 2021;13:195-196

DOI: $10.1159 / 000517261$
Received: May 16, 2021

Accepted: May 18, 2021

Published online: June 9, 2021

\title{
Once Upon a Time
}

During the emerging COVID-19 pandemic, development of vaccines and the attempt to establish herd immunity have moved into the focus of clinical research. As a result, a great deal of scientific activities have been devoted to adaptive immunity and how it can be used to fight the SARS-CoV-2 virus. However, also innate immunity plays important roles in mounting protection against viral infections. For instance, it was recently reported that Tollip, a negative immune regulator, can inhibit the proinflammatory response to rhinovirus infection [1], that toll-like receptor 3 can induce interleukin (IL)-1 receptor antagonist expression leading to an induction of anti-inflammatory reactions [2], and that gender-specific hormones such as $17 \beta$-estradiol can modulate the innate immune response to viral infections [3]. In addition, we also published that interferons are crucial players in the fight against viral infections as they enhance the innate immune response against many viral pathogens [4-6].

Neutrophils are another important player in this context as they contribute to eradication of viral infections [7, 8]. Thus, a better understanding of the molecular mechanisms that these cells use to counteract an invading virus may be of great help for future development of novel antiviral therapies. It is therefore foresighted not to neglect the study of these immune cells. In the present issue of the Journal of Innate Immunity we publish 4 articles, all dealing with the role of neutrophils as immune-modulatory cells [9-12].

In the first article of this issue, Abdel-Razek et al. [9] describe an important role of surfactant protein D (SP-D) in an experimental model of otitis media. The authors employed a non-typeable Haemophilus influenzae-induced mouse model to show that neutrophil recruitment to the middle ear was decreased in SP-D knockout mice

karger@karger.com www.karger.com/jin Karger
(C) 2021 The Author(s)

Published by S. Karger AG, Basel

This is an Open Access article licensed under the Creative Common Attribution-NonCommercial-4.0 International License (CC BY-NC) (http://www.karger.com/Services/OpenAccessLicense), applicable to the online version of the article only. Usage and distribution for commercial purposes requires written permission. when compared with wild-type animals. Overall, the authors came to the conclusion that SP-D can enhance the host defense through regulation of NF- $\kappa \mathrm{B}$ and NLRP3associated inflammasome activation [9]. Similar to SP-D, also other proteins such as Siglec-14, a glycan-recognition protein that is expressed on myeloid cells, trigger inflammasome activation via NLRP3 [13]. These findings suggest that NLRP3-induced inflammasome activation is an important host defense mechanism that helps to clear invading pathogens.

In the second article of this issue, Rosbjerg et al. [10] investigated 2 proteins involved in regulation of the lectin pathway of the complement system, i.e. MASP-1 and MASP-3, respectively. The authors describe that the 2 proteins bind directly to the surface of Aspergillus fumigatus, a fungal pathogen. Neutrophils were used in this study to follow the fungal uptake. These experiments show that, in addition to their enzymatic function as serine proteinases, MASP- 1 and MASP-3 can also act as pattern recognition molecules [10].

The third article, written by Bernhard et al. [11], deals with IL-8 [11]. The authors found that IL-8 elicits rapid physiological changes in neutrophils that are altered by inflammatory conditions such as fMLP or LPS [11]. Notably, IL-8 levels are increased for instance under inflammatory conditions such as trauma [14] and thus the study of this critical chemotactic factor will be of help to understand how inflammatory responses can be modulated. To this end, the authors report that ion channels and transporters play an important role in these processes which allowed them conclude that targeting these proteins can be used for diagnostic purposes [11].

In the last article of this issue, Mårtensson et al. [12] examined how 2 formyl peptide receptors (FPR1 and 
FPR2) can regulate GPR84-mediated neutrophil NADPH oxidase activity and subsequent production of reactive oxygen species [12]. It was demonstrated that the 2 responses are evoked by different agonist recognition profiles, leading to distinct desensitization and reactivation patterns of the 2 receptors. Based on these findings the authors came to the conclusion that increased knowledge of the molecular mechanisms behind functional receptor regulation can be used to control a wide array of pathologies [12].

\section{References}

1 Dakhama A, Al Mubarak R, Pavelka N, Voelker D, Seibold M, Ledford JG, et al. Tollip inhibits st2 signaling in airway epithelial cells exposed to type 2 cytokines and rhinovirus. J Innate Immun. 2020;12(1):103-15.

2 Liu Y, Mo CF, Luo XY, Li H, Guo HJ, Sun H, et al. Activation of toll-like receptor 3 induces interleukin-1 receptor antagonist expression by activating the interferon regulatory factor 3. J Innate Immun. 2020;12(4):304-20.

3 McKiernan PJ, Smith SG, Durham AL, Adcock IM, McElvaney NG, Greene CM. The estrogen-induced mir-19 downregulates secretory leucoprotease inhibitor expression in monocytes. J Innate Immun. 2020;12(1):90102.

4 Kikkert M. Innate immune evasion by human respiratory rna viruses. J Innate Immun. 2020; 12(1):4-20.

$5 \mathrm{Wu} \mathrm{W}$, Metcalf JP. The role of type i ifns in influenza: antiviral superheroes or immunopathogenic villains? J Innate Immun. 2020; 12(6):437-47.
All together, the 4 articles published in this issue of the Journal of Innate Immunity prove that studying innate immune cells is as important today as it was before the COVID-19 outbreak. As always, we hope that the collection of articles will be of interest to the readership of the Journal of Innate Immunity and contribute to a better understanding of the fundamental mechanisms used by the innate immune system to protect us from invading microorganisms.
Heiko Herwald, Lund Arne Egesten, Lund
6 Mihm S. Covid-19: possible impact of the genetic background in ifnl genes on disease outcomes. J Innate Immun. 2020;12(3):273-4.

7 Lemaitre J, Cosma A, Desjardins D, Lambotte O, Le Grand R. Mass cytometry reveals the immaturity of circulating neutrophils during sivinfection. J Innate Immun. 2020;12(2):170 81.

8 Andersson AM, Larsson M, Stendahl O, Blomgran R. Efferocytosis of apoptotic neutrophils enhances control of mycobacterium tuberculosis in hiv-coinfected macrophages in a myeloperoxidase-dependent manner. Innate Immun. 2020;12(3):235-47.

9 Abdel-Razek O, Liu T, Chen X, Wang Q, Vanga $G$, Wang G. Role of surfactant protein d in experimental otitis media. J Innate Immun. 2021. doi: 10.1159/000513605.

10 Rosbjerg A, Würzner R, Garred P, Skjoedt MO. Masp-1 and masp-3 bind directly to aspergillus fumigatus and promote complement activation and phagocytosis. J Innate Immun. 2021. doi: 10.1159/000514546.
11 Bernhard S, Hug S, Stratmann AE, Erber M, Vidoni L, Knapp CL, et al. Interleukin 8 elicits rapid physiological changes in neutrophils that are altered by inflammatory conditions. J Innate Immun. 2021. doi: 10.1159/000514885.

12 Mårtensson J, Sundqvist M, Manandhar A, Leremias L, Zhang L, Ulven T, et al. The two formyl peptide receptors differently regulate gpr84-mediated neutrophil nadph oxidase activity. J Innate Immun. 2021. doi: 10.1159/ 000514887.

13 Tsai CM, Riestra AM, Ali SR, Fong JJ, Liu JZ, Hughes G, et al. Siglec-14 enhances nlrp3-inflammasome activation in macrophages. J Innate Immun. 2020;12(4):333-43.

14 Jo YG, Kim JC, Jin HM, Cho YN, Kee SJ, Park YW. Natural killer t cells are numerically and functionally deficient in patients with trauma. J Innate Immun. 2020;12(4):344-54. 